\title{
PENGARUH ISLAMIC SERVICE QUALITY DAN BRAND IMAGE TERHADAP KEPUASAN NASABAH
}

\author{
Liya Setiawati \\ Email: liya.setiawati@gmail.com \\ Alumni Mahasiswa Magister Manajemen Pascasarjana Unisba \\ Program Studi Magister Manajemen Unisba, Bandung, Indonesia
}

\begin{abstract}
Abstrak. Penelitian ini bertujuan untuk mengetahui pengaruh kualitas layanan Islami dan Brand image terhadap Kepuasan nasabah, studi kasus pada Bank Republik Indonesia (BRI) Syariah Kantor Cabang Induk Citarum, Bandung. Kualitas layanan Bank syariah di Indonesia masih menghadapi beberapa kendala antara lain pemahaman sumber daya manusia tentang syariah yang masih kurang dan keterbatasan jaringan kantor sehingga pangsa pasar perbankan syariah di indonesia baru mencapai $4.83 \%$. Penelitian ini menggunakan metode deskriptif verifikatif. Alat analisa yang digunakan adalah analisis jalur, untuk mengetahui pengaruh langsung maupun tidak langsung Islamic Service Quality dan Brand Image terhadap kepuasan nasabah. Teknik pengumpulan data menggunakan kuesioner. Sampel penelitian ini sebanyak 100 nasabah dengan teknik pengumpulan mengunakan Accidental sampling. Hasil penelitian ini menunjukan bahwa secara simultan maupun parsial Islamic Service Quality dan Brand Image berpengaruh signifikan terhadap kepuasan nasabah. Islamic service quality lebih besar pengaruhnya terhadap kepuasan nasabah dibandingkan brand image terhadap kepuasan nasabah, saran peneliti untuk BRI Syariah agar senantiasa mengelola atau menjalankan strategi kualitas pelayanan para Front Officer dengan dinamis, tidak baku dan disesuaikan kondisi yang terjadi namun tetap dilandasi dengan nilai-nilai keislaman, tanpa unsurnya riba. Sehingga meskipun kondisi di lapangan bersifat dinamis, namun pencapaian visi BRI Syariah sebagai bank syariah terpercaya dapat tercapai dengan baik.
\end{abstract}

Keywords : islamic service quality, brand image, kepuasan nasabah

\section{Pendahuluan}

Indonesia merupakan salah satu negara yang mayoritas penduduknya menganut agama Islam dan negara dengan populasi Muslim terbesar didunia, yaitu 87\% (World Muslim Population, 2017).

Karakteristik budaya Indonesia sangat dipengaruhi oleh prinsip hukum Islam dan nilai-nilai agama Islam, termasuk didalamnya perkembangan perbankan syariah di Indonesia yang sangat pesat. Tetapi total pangsa pasar Bank Umum Syariah dan Unit Usaha Syariah baru mencapai $4,83 \%$ dari total sektor perbankan pada akhir tahun 2015. (Mulya Siregar 2016).

Pangsa pasar ini dianggap relatif rendah bila dibandingkan dengan negara-negara Islam lainnya dengan populasi dan tingkat ekonomi yang jauh lebih kecil, yaitu Malaysia dan Arab Saudi. Di masing-masing negara tersebut, pangsa pasar perbankan syariah mencapai $20 \%$ dan 53\% dari total pasar perbankan domestik. (Masterplan Arsitektur Keuangan Syariah Indonesia-Bapenas : 2016).

Rendahnya pangsa pasar perbankan syariah di Indonesia yang notabene penduduknya mayoritas beragama Islam menimbulkan berbagai pertanyaan mengenai penyebabnya, apakah nasabah perbankan di Indonesia kurang tertarik dengan bank syariah atau mereka sebenarnya tertarik dengan konsep perbankan syariah namun berpendapat kualitas bank syariah belum dapat menyamai kualitas bank-bank konvensional.

Bank syariah di Indonesia masih menghadapi beberapa kendala antara lain pemahaman masyarakat yang masih kurang, peraturan perbankan, keterbatasan jaringan kantor, sumber daya manusia (Bank Indonesia, 2002)

Salah satu permasalahannya berasal dari Sumber daya manusia bank syariah yang direkrut berasal dari bank konvensional, dan mereka membawa kultur dan cara berfikir bank konvensional sehingga tidak terlihat perbedaan jasa layanannya dengan bank konvensional.

Hal ini menunjukkan bahwa bank syariah merupakan sebuah Perusahaan jasa Keuangan yang sedang berkembang dan masih memerlukan perbaikan serta secara tidak langsung dapat menggambarkan rendahnya tingkat kepuasan nasabah perbankan Indonesia terhadap bank syariah. Sedangkan Kepuasan nasabah akan dipengaruhi oleh kualitas 
pelayanan yang diberikan oleh penyedia jasa (Fandy Tjiptono (2006).

Untuk meningkatkan pangsa pasar perbankan syariah di Indonesia maka praktisi bank syariah perlu meningkatkan kualitas pelayanan bagi nasabahnya. Hal ini dikarenakan kualitas pelayanan merupakan salah satu faktor kunci keberhasilan Bank Syariah sebagai perusahaan jasa.

Secara konsep, pelayanan pada bank syariah disandarkan kepada ketentuan yang terdalam dalam Al-Qur`an dan Sunnah Rasul sebagai panduan hidup bagi umat Islam. Produk dan layanan bank syariah dipersiapkan sebagai produk dan layanan yang berkualitas tinggi untuk konsumen. Sesuai dengan salah satu hadits yang driwayatkan oleh Imam AtTabrani dan Imam Baihaqi sebagai berikut:

"Dari Aisyah, bersabda Rasulullah S.A.W: Allah azza wa jalla menyukai jika salah seorang diantara kalian melakukan suatu amal secara itqan."

Kata "Itqan" pada hadits di atas dalam bahasa Arab sering digunakan untuk menunjukkan kualitas dari pekerjaan. Itqan artinya mempersiapkan dan memberikan hasil terbaik atau melakukan segala sesuatu dengan kualitas tinggi.

Kualitas layanan yang baik dalam bank syariah menjadi penting karena akan berhubungan dengan biaya, keuntungan, kepuasan konsumen, ingatan konsumen, serta kata-kata positif dari mulut konsumen. (Othman dan Owen 2001)

Pentingnya penerapan kualitas pelayanan di bank syariah adalah karena produk dan layanan bank syariah harus diterima sebagai produk dan layanan yang berkualitas tinggi oleh konsumen. Allah senang melihat pekerjaan selesai pada tingkat Itqan yang artinya mempersiapkan dan memberikan hasil terbaik atau melakukan segala sesuatu dengan kualitas tinggi.

Kemudian hal lain yang dianggap sebagai alasan pentingnya penerapan kualitas layanan yang baik di bank syariah adalah karena hubungannya dengan biaya,keuntungan, kepuasan konsumen, ingatan konsumen, serta kata-kata positif dari mulut konsumen. (M. Antonio Syafi'i, 2000)

Selain itu juga brand bank syariah seharusnya memiliki tingkat kedekatan yang tinggi dengan para nasabah muslim karena seharusnya memberikan kenyamanan dalam melaksanakan transaksi perbankan dan kegiatan muamalat lainnya pada umumnya yang sesuai dengan ketentuan dan ajaran Islam.

Kini nasabah lebih cenderung menyukai brand yang terkenal dibandingkan dengan fungsi utama dari produk tersebut, memang tidak dapat dipungkiri bahwa brand yang terkenal mencerminkan mutu yang terjamin. Melalui citra merek yang kuat, maka pelanggan akan memiliki asumsi positif terhadap merek dari produk yang ditawarkan oleh suatu bank.

BRI Syariah merupakan salah satu perusahaan perbankan yang ada di Indonesia dan menjadi bank komersial terkemuka yang selalu mengutamakan kepuasan nasabah serta memberikan pelayanan terbaik kepada nasabah melalui jaringan kerja yang tersebar luas dan didukung oleh sumber daya manusia yang profesional agar dapat memberikan keuntungan dan manfaat yang optimal kepada pihak-pihak yang berkepentingan.

Kehadiran BRI Syariah dalam industri perbankan syariah di Indonesia diharapkan dapat memberikan pelayanan yang terbaik dalam memenuhi kebutuhan para nasabahnya melalui produk penyimpanan dan pendanaan yang berbasis syariah, berikut pra survey dari 20 nasabah mengenai kualitas layanan Bank BRI Syariah Cab Citarum: 
Tabel 1.1

Pra Survey Mengenai Kualitas Layanan BRI Syariah KCI Citarum (Kep Kopo, Kcp Setiabudhi, Kcp Cimahi, Kcp Cijerah)

\begin{tabular}{|c|c|c|c|c|c|c|c|}
\hline \multirow{3}{*}{ No } & & \multicolumn{5}{|c|}{ Hasil } & \multirow[b]{2}{*}{$\begin{array}{c}\text { Jumla } \\
\mathrm{h}\end{array}$} \\
\hline & $\begin{array}{l}\text { Pertan } \\
\text { yaan }\end{array}$ & $\begin{array}{c}\text { Sang } \\
\text { at } \\
\text { Puas }\end{array}$ & Puas & $\begin{array}{l}\text { Cuku } \\
\text { p } \\
\text { Puas }\end{array}$ & $\begin{array}{l}\text { Tidak } \\
\text { Puas }\end{array}$ & $\begin{array}{c}\text { Sang } \\
\text { at } \\
\text { Tidak } \\
\text { Puas } \\
\end{array}$ & \\
\hline & & 5 & 4 & 3 & 2 & 1 & \\
\hline 1 & $\begin{array}{l}\text { Gedun } \\
\text { g Yang } \\
\text { dimiliki }\end{array}$ & 0 & 5 & 6 & 8 & 1 & 20 \\
\hline 2 & $\begin{array}{c}\text { Fasilita } \\
\text { s fisik } \\
\text { yang } \\
\text { dimiliki }\end{array}$ & 0 & 3 & 7 & 8 & 2 & 20 \\
\hline 3 & $\begin{array}{c}\text { Keram } \\
\text { ahan } \\
\text { Karyaw } \\
\text { an }\end{array}$ & 1 & 4 & 7 & 6 & 2 & 20 \\
\hline 4 & $\begin{array}{c}\text { Keperc } \\
\text { ayaan } \\
\text { bank } \\
\text { kepada } \\
\text { karyaw } \\
\text { an }\end{array}$ & 2 & 7 & 6 & 5 & 0 & 20 \\
\hline \multicolumn{2}{|c|}{$\begin{array}{l}\text { Persentase Rata- } \\
\text { rata (\%) }\end{array}$} & 3.75 & $\begin{array}{c}23.75 \\
\%\end{array}$ & $\begin{array}{c}32.5 \\
\%\end{array}$ & $\begin{array}{c}33.75 \\
\%\end{array}$ & $\begin{array}{c}6.25 \\
\%\end{array}$ & $100 \%$ \\
\hline
\end{tabular}

Tabel 1.2

Pra Survey Mengenai Brand ImagePerusahaan pada BRI Syariah KCI Citarum (Kcp Kopo, Kcp Setiabudhi, Kcp Cimahi, Kcp Cijerah)

\begin{tabular}{|c|c|c|c|c|c|c|c|}
\hline \multirow{2}{*}{$\mathrm{N}$} & & \multicolumn{5}{|c|}{ Hasil } & \\
\cline { 2 - 7 } & $\begin{array}{c}\text { Pertanyaa } \\
\mathrm{n}\end{array}$ & $\begin{array}{c}\text { Sanga } \\
\mathrm{t} \\
\text { Setuj } \\
\mathrm{u}\end{array}$ & $\begin{array}{c}\text { Setuj } \\
\mathrm{u}\end{array}$ & Ragu & $\begin{array}{c}\text { Tidak } \\
\text { Setuj } \\
\mathrm{u}\end{array}$ & $\begin{array}{c}\text { Sanga } \\
\mathrm{t} \\
\text { Tidak } \\
\text { Setuj } \\
\mathrm{u}\end{array}$ & $\begin{array}{c}\text { Jumla } \\
\mathrm{h}\end{array}$ \\
\cline { 2 - 7 } & $\begin{array}{c}\text { Bank Bri } \\
\text { Syariah } \\
\text { memiliki } \\
\text { merk } \\
\text { yang } \\
\text { dikenal }\end{array}$ & 0 & 2 & 7 & 11 & 0 & 20 \\
\hline $\begin{array}{c}\text { BRI } \\
\text { Syariah } \\
\text { mudah } \\
\text { diingat } \\
\text { oleh } \\
\text { nasabah }\end{array}$ & 0 & 1 & 8 & 11 & 0 & 20 \\
\hline $\begin{array}{c}\text { Persentase } \\
\text { Rata-rata (\%) }\end{array}$ & $0 \%$ & $7.5 \%$ & 37.5 & $55 \%$ & $0 \%$ & $100 \%$ \\
\hline \multicolumn{6}{|c|}{ Sumber : Data olahan Penulis, 2017 } & & \\
\hline
\end{tabular}

Dari keterangan tabel di atas, terlihat bahwa sebanyak 55\% responden menyatakan tidak setuju dan $37.5 \%$ menyatakan ragu bahwa BRI Syariah memiliki merk yang dikenal sebagai bank syariah oleh masyarakat luas. Hal ini tentu harus menjadi catatan dan perhatian bagi jajaran manajemen BRI Syariah, karena BRI Syariah kurang dikenal dimasyarakat atau bahkan diketahui oleh masyarakat. Dengan demikian, maka brand image yang dimiliki BRI Syariah harus benarbenar dijadikan salah satu aspek untuk meningkatkan kepuasan nasabah. 
Tabel 1.3

Pra Survey Mengenai Kepuasan Nasabah di BRI Syariah KCI Citarum

(Kcp Kopo, Kcp Setiabudhi, Kcp Cimahi, Kcp Cijerah)

\begin{tabular}{|c|c|c|c|c|c|c|c|}
\hline \multirow{3}{*}{ No } & \multirow[b]{2}{*}{ Pertanyaan } & \multicolumn{5}{|c|}{ Hasil } & \multirow[b]{2}{*}{ Jumlah } \\
\hline & & $\begin{array}{l}\text { Sangat } \\
\text { Puas }\end{array}$ & Puas & $\begin{array}{c}\text { Cukup } \\
\text { Puas }\end{array}$ & $\begin{array}{l}\text { Tidak } \\
\text { Puas }\end{array}$ & $\begin{array}{c}\text { Sangat } \\
\text { Tidak } \\
\text { Puas }\end{array}$ & \\
\hline & & 5 & 4 & 3 & 2 & 1 & \\
\hline 1 & $\begin{array}{c}\text { Saya merasa puas } \\
\text { atas layanan yang } \\
\text { diberikan BRI } \\
\text { Syariah }\end{array}$ & 1 & 3 & 5 & 8 & 3 & 20 \\
\hline 2 & $\begin{array}{c}\text { Saya akan } \\
\text { merekomendasikan } \\
\text { produk dan jasa } \\
\text { BRI Syariah kepada } \\
\text { orang lain }\end{array}$ & 1 & 3 & 5 & 9 & 2 & 20 \\
\hline 3 & $\begin{array}{c}\text { Menurut saya } \\
\text { pelayanan di BRI } \\
\text { Syariah merupakan } \\
\text { pelayanan terbaik } \\
\text { dibanding bank } \\
\text { yang lain } \\
\end{array}$ & 1 & 3 & 6 & 8 & 2 & 20 \\
\hline & Persentase (\%) & $5 \%$ & $15 \%$ & $26.7 \%$ & $41.7 \%$ & $11.6 \%$ & $100 \%$ \\
\hline
\end{tabular}

Sumber : Data olahan Penulis, 2017

Berdasarkan hasil tabel di atas dapat disimpulkan bahwa tingkat kepuasan nasabah dirasakan kurang karena $41.7 \%$ hanya menyatakan tidak puas dan sebanyak $11.6 \%$ bahkan menyatakan sangat tidak puas atas layanan yang diberikan BRI Syariah. Dengan demikian, hal tersebut menunjukan service quality dan brand image yang diberikan kepada nasabah belum memenuhi kepuasan nasabah hal tersebut menjadikan latar belakang masalah yang akan diteliti pada Bank BRI Syariah Kantor Cabang Induk (KCI) Citarum Kota Bandung.

\section{Pembahasan}

\section{a. Kualiats Layanan Islami}

Dimensi Kualitas layanan secara umum para peneliti menggunakan acuan lima dimensi kualitas pelayanan (SERVQUAL/Service Quality) yang dikembangkan oleh Parasuraman, Zeithmal dan Berry yaitu assurance, reliability, tangible, empathy dan responsiveness. Namun dimensi kualitas layanan tersebut bersifat general, sehingga jika diterapkan pada perusahaan yang memiliki karakteristik spesifik memerlukan modifikasi seperti perusahaan perbankan Islam (syariah). (Zeithaml, L. Valerie A., Parasuraman, A.,Berry, Leonardo L., 1988)

Berdasarkan hal tersebut, Othman dan Owen menyodorkan dimensi CARTER untuk mengukur kualitas layanan perbankan Islam yang dikembangkan dari konsep SERVQUAL, dengan tambahan dimensi compliance. Sedangkan dimensi yang lain sama dengan dimensi dalam SERVQUAL. CARTER merupakan singkatan dari enam dimensi kualitas layanan yaitu Compliance, Assurance, Reliability, Tangibles, Empathy, Responsiveness.

\section{Compliance}

Kemampuan perusahaan atas kesesuaian dalam penerapan prinsip syariah meliputi menjalankan kegiatan perusahaan sesuai dengan prinsip Islam, menerapkan ketentuan layanan dan produk Islam.

\section{Assurance}

Dalam Islam, memberikan pelayanan harus bersikap lemah lembut, menghilangkan sikap keras hati dan harus memiliki sikap pemaaf kepada nasabah supaya nasabah terhindar dari rasa takut, tidak percaya dan perasaan adanya bahaya dari pelayanan yang diterima.

\section{Reliability}

Kemampuan perusahaan untuk memberikan pelayanan sesuai dengan yang dijanjikan secara akurat dan terpercaya. Kinerja harus sesuai dengan harapan pelanggan yang berarti ketepatan waktu pelayanan yang sama untuk semua pelanggan tanpa kesalahan, sikap yang simpatik dan dengan akurasi yang tinggi.

\section{Tangibles}

Kemampuan perusahaan dalam menunjukkan eksistensinya kepada eksternal, penampilan dan kemampuan sarana dan prasarana fisik perusahaan.

\section{Empathy}

Memberikan perhatian yang tulus bersifat individual atau pribadi yang diberikan kepada para pelanggan dengan berupaya untuk memahami keinginan konsumen.

\section{Responsiveness}

Suatu kemauan untuk membantu dan memberikan pelayanan yang cepat (responsive) dan tepat pada pelanggan dengan penyampaian informasi yang jelas.

\section{b. Brand Image}

Islam merupakan agama yang menjunjung tinggi kepada umatnya untuk saling mengenal antara satu dengan yang lain, karena pada hakikatnya manusia adalah makhluk sosial yang saling membutuhkan antara satu dengan yang lain dalam kehidupan sehari-hari. Kegiatan saling mengenal antara seseorang 
dengan orang disekitarnya juga tercantum dalam Al-Qur'an pada surat Al-Hujuraat ayat 13 sebagai berikut :

"Hai manusia, sesungguhnya kami menciptakan kamu dari seorang laki-laki dan seorang perempuan dan menjadikan kamu berbangsa-bangsa dan bersuku-suku supaya kamu saling mengenal, sesungguhnya orang yang paling mulia di antara kamu di sisi Allah ialah orang yang paling bertaqwa diantara kamu. Sesungguhnya Allah Maha Mengetahui lagi Maha Mengenal" (Q.S Al-Hujurat :13)

Citra produk merupakan suatu tampilan produk, dalam islam sendiri penampilan produk tidak membohongi pelanggan, baik menyangkut besaran kuantitas maupun kualitas. Hal ini sesuai dengan surat AsySyu'ara' ayat 181-183 yang berbunyi :

"Sempurnakanlah takaran dan jaganlah kamu termasuk orang-orang yang merugikan; dan timbanglah dengan timbangan yang lurus. Dan janganlah kamu merugikan manusia pada hak-haknya dan janganlah kamu merajalela di muka bumi dengan membuat kerusakan" (Al Qur'an dan Terjemahannya. 2005)

Ayat Asy-Syu'ara' ayat 181-183

memberikan pedoman bahwa pentingnya menjaga kualitas produk yang kita jual yaitu dengan tidak memanipulasi atau merugikan pembeli.

\section{c. Kepuasan Nasabah}

Menurut Kotler, kepuasan nasabah (customer) adalah tingkat perasaan seseorang setelah membandingkan kinerja atau hasil yang dia rasakan dibandingkan dengan harapannya (Kotler dkk, 2000 : 52)

Kepuasan nasabah merupakan evaluasi purna beli dimana alternatif yang dipilih sekurang-kurangnya sama atau melampaui harapan nasabah, sedangkan ketidak puasan timbul apabila hasil (outcome) tidak memenuhi harapan (Tjiptono, $2004: 349$ )

Kepuasan nasabah terhadap suatu produk ataupun jasa, sebenarnya sesuatu yang sulit untuk didapat jika perusahaan jasa atau

Menurut pendapat Qardhawi (1997), sebagai pedoman untuk mengetahui tingkat kepuasan yang dirasakan oleh konsumen, maka sebuah perusahaan barang maupun jasa harus melihat kinerja perusahaannya yang berkaitan dengan:

1. Sifat Jujur

Sebuah perusahaan harus menanamkan sifat jujur kepada seluruh personel yang terlibat dalam perusahaan tersebut

2. Sifat Amanah

Amanah adalah mengembalikan hak apa saja kepada pemiliknya, tidak mengambil sesuatu melebihi haknya dan tidak mengurangi hak orang lain, baik berupa harga ataupun yang lainnya

3. Benar

Berdusta dalam berdagang sangat dikecam dalam Islam, terlebih lagi jika disertai dengan sumpah palsu atas nama Allah.

\section{d. Metode Penelitian}

Penelitian ini memiliki dua sifat yakni deskriptif dan verifikatif yaitu metode yang bertujuan untuk menguji secara matematis dugaan mengenai adanya hubungan antara variabel dan masalah yang diselidiki didalam hipotesis.

Untuk dapat mencapai tujuan penelitian pertama dan kedua dalam penelitian ini, yaitu untuk mengetahui tanggapan nasabah mengenai kualitas pelayanan secara islami dan brand image teradap kepuasan nasabah pada Bank BRI Syariah Cab Citarum maka dilakukan penelitian yang berjenis deskriptif dengan menggunakan sumber data primer yang diperoleh dari hasil observasi dan wawancara kepada nasabah BRI Syariah hasil penyebaran kuesioner.

Variabel penelitian antara lain: Islamic Sevice Quality (X1), Brand Image (X2) dan Kepuasan Nasabah (Y). Islamic Service Quality terdiri dari 6 indikator: compliance dengan 5 butir pertanyaan, assurance dengan 5 butir pertanyaan, reliability dengan 5 butir pertanyaan, tangible dengan 5 butir pertanyaan, empathy dengan 5 butir pertanyaan, dan responsiveness dengan 5 butir pertanyaan. Variabel Brand Image terdiri dari 5 indikator yang juga digunakan sebagai butir item pertanyaannya, begitu pula dengan variabel Kepuasan Nasabah terdiri dari 5 indikator yang juga digunakan sebagai butir item pertanyaannya.

Populasi dalam penelitian ini adalah nasabah yang telah melakukan pembukaan rekening baru periode 2014-2016 di Bank Bank BRI Syariah Cab Citarum sebagai berikut : 
Tabel 2.1

Populasi Bri Syariah Cab Citarum

\begin{tabular}{|l|l|l|l|l|l|}
\hline No & $\begin{array}{l}\text { Nama } \\
\text { Cabang }\end{array}$ & $\mathbf{2 0 1 4}$ & $\mathbf{2 0 1 5}$ & $\mathbf{2 0 1 6}$ & total \\
\hline 1 & KC Citarum & 926 & 806 & 878 & 2610 \\
\hline 2 & KCP Kopo & 225 & 208 & 187 & 620 \\
\hline 3 & KCP Cijerah & 189 & 247 & 230 & 666 \\
\hline 4 & KCP Cimahi & 374 & 229 & 245 & 848 \\
\hline 5 & $\begin{array}{l}\text { KCP } \\
\text { Setiabudhi }\end{array}$ & 326 & 349 & 310 & 985 \\
\hline & \multicolumn{2}{|l}{ Total Populasi } & & $\mathbf{5 7 2 9}$ \\
\hline
\end{tabular}

Sumber : BRI Syariah Cab Citarum, 2017.

Sampel dalam penelitian ini adalah jumlah nasabah hingga periode Desember 2016 yang terdapat di KCP Bandung Kopo, Kcp Bandung Cijerah, Kcp Bandung Setiabudhi, Kcp Bandung Cimahi dan KC Bandung Citarum. Mengingat populasi dapat ditentukan secara tepat maka untuk menentukan ukuran sampel dari suatu populasi digunakan rumus Slovin sebagai berikut (Slovin dalam Hussein Umar, 2007:78)

$$
n=\frac{N}{1+N e^{2}}
$$

Dimana :

$\mathrm{n}=$ Ukuran sampel

$\mathrm{N}=$ Ukuran populasi

$\mathrm{e}=$ Persen kelonggaran ketidaktelitian karena kesalahan pengambilan sampel yang masih dapat ditolelir atau diinginkan sebesar $10 \%$ atau 0.1

Berdasarkan informasi dari pihak manajemen, jumlah nasabah yang membuka rekening selama 3 tahun terakhir yaitu sebanyak orang 5729 dengan perhitungan :

$$
\begin{aligned}
& \mathrm{n}=\frac{5729}{\left(1+3773 \times .0 .1^{2)}\right.} \\
& \mathrm{n}=98.28444
\end{aligned}
$$

Jumlah kuisioner yang disebar sebanyak 100 kuisioner, yang memenuhi kriteria adalah sebanyak 100 sehingga responsnya sebesar $100 \%$. Kuesioner yang dianalisis adalah yang layak, artinya semua butir item sudah dijawab oleh responden. Teknik analisis yang digunakan adalah Partial Least Square (PLS) dengan program Smart PLS.
Metode pengambilan sampel sebanyak 100 responden dilakukan dengan menggunakan teknik Accidental sampling yaitu dikenakan pada individu atau nasabah yang dijumpai dan dapat diselidiki dibank BRIS KC Citarum, KCP Kopo, KCP Cimahi, KCP Cijerah dan KCP Setiabudhi.

Skala Pengukuran Dalam penelitian ini, menggunakan skala Likert, yaitu memberikan ranking terhadap responden bisa berupa preferensi, perilaku dan sebagainya (Bawono, 2006: 31).

Skala Likert digunakan untuk menjawab bagian pernyataan penelitian, kategori skala ini terdiri dari 5 tingkatan yaitu, Sangat Baik (5), Baik (4), Netral (3) , Tidak Baik (2), dan Sangat Tidak Baik (1)

\section{e. Uji Validitas dan Reliabilitas}

Seluruh item pada variabel dalam penelitian ini dinyatakan valid dengan mengacu pada ketentuan jika hasil corrected item total correlation lebih dari 0.197 maka kuesioner dikatakan valid.

\section{f. Uji Reliabilitas}

Tingkat croncbach alpha yang diperoleh dari dalam penelitian ini adalah sebesar 0.969 untuk variabel $\mathrm{X}_{1}, 0.839$ untuk variabel $\mathrm{X}_{2}$ dan 0.816 untuk variabel Y. Hasil yang diperoleh dari kuesioner untuk variabel (Islamic Service Quality, Kepuasan Nasabah dan Brand Image) yaitu croncbach alpha > $\mathrm{r}$ tabel product moment $(0,600)$ yang menunjukan bahwa data yang telah penulis sebarkan adalah reliable.

\section{g. Analisis Koefisien Korelasi}

Hasil pengujian koefisien korelasi bahwa terdapat hubungan yang sangat kuat antara Islamic Service Quality dengan Kepuasan Nasabah koefisien korelasi 0.822, terdapat hubungan yang kuat antara Brand Image dengan Kepuasan Nasabah koefisien korelasi 0.777, dan terdapat hubungan yang sangat kuat antara Islamic Service Quality dengan Brand Image koefisien korelasi 0.841 .

\section{h. Analisis Jalur, Pengaruh Langsung dan Tidak Langsung}


Gambar 2.2

Hasil Analisis Koefisien Jalur

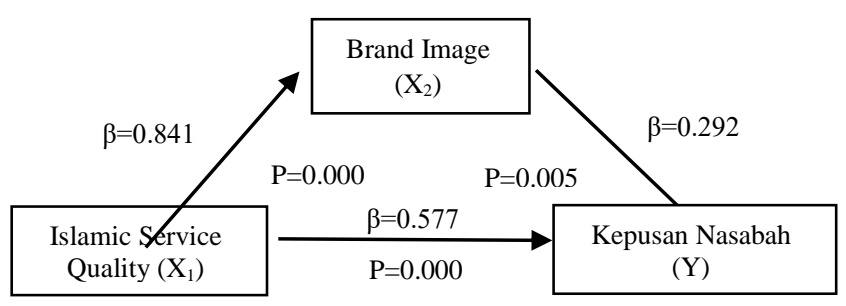

Berdasarkan model-model pengaruh tersebut, dapat disusun Model Lintasan pengaruh sebagai berikut. Model Lintasan ini disebut dengan Analisis Jalur (Path Analysis), dimana pengaruh error ditentukan sebagai berikut:

1. Pengaruh dari $X_{1}$ ke $X_{2}$

Pengaruh langsung $=0.841$

Total pengaruh $=0.841$

2. Pengaruh dari $X_{2}$ ke $Y$

Pengaruh langsung $=0.292$

Pengaruh tak langsung $=(0.292 \times 0.577)=$ 0.168

Total pengaruh $=0.292+0.168=0.460$

3. Pengaruh dari $\mathrm{X}_{1}$ ke $\mathrm{Y}$

Pengaruh langsung $=0.577$

Pengaruh tak langsung $=(0.577 \times 0.292)=$ 0.168

Total pengaruh $=0.577+0.168=0.745$

Penjelasan :

Lebih besar pengaruh langsung dari Islamic Service Quality pada Brand Image dibanding Brand Image terhadap Kepuasan Nasabah, dan besar pengaruh juga dari Islamic Service Quality terhadap Kepuasan Nasabah.

Hal ini menandakan bahwa Islamic Service Quality sangat erat kaitannya dengan Brand Image, Pelayanan pada Bank sangat berkaitan dengan merk yang dimiliki Bank, jika keduanya unggul maka akan menghasilkan.

Kepuasan Nasabah yang signifikan. dan kepuasan nasabah lebih besar pengaruhnya dengan Islamic Service Quality dibanding Brand Image, Pelayanan yang baik menghasilkan Kepuasan terhadap nasabah, tetapi merk yang Bagus belum tentu menghasilkan kepuasan terhadap nasabah.

\section{i. Uji Hipotesis}

Untuk nilai Standardized Coefficients Beta pada analisis regresi ini sebesar 0.577, nilai Standardized Coefficients Beta ini merupakan nilai path atau jalur. Sedangkan nilai koefisien regresi $(\beta)$ variabel Islmic Service Quality pada BRI Syariah KCI Citarum sebesar 0.100 dan nilai t-test sebesar 5.632 dengan nilai signifikansi 0.000 . Hal ini menunjukkan bahwa $t$-test sebesar 5.632 lebih besar dari $t$ tabel sebesar 1.984, serta signifikansi 0.000 lebih kecil dari $\alpha$ sebesar 0.05 , sehingga dengan demikian dapat disimpulkan bahwa hasil ini menunjukan hubungan antara Islmic Service Quality dengan tingkat kepuasan nasabah adalah signifikan.

\section{j. Hasil Uji Signifikan Simultan (Uji F)}

Diperoleh nilai $\mathrm{F}_{\text {hitung }} 113.724$ dan tingkat signifikansi $0.000<0,05$. Setelah mengetahui besarnya $F_{\text {hitung, maka akan dibandingkan }}$ dengan $F_{\text {tabel. }}$ Adapun hasil $F_{\text {tabel }}$ yang diperoleh dengan $\mathrm{dk}_{1}=2$ dan $\mathrm{dk}_{2}=100-2-1$ $=97$ dan taraf kesalahan 5\% adalah 3.15, maka $F_{\text {hitung }}(113.724)>F_{\text {tabel }}$ (3.15). Berdasarkan hasil tersebut dapat disimpulkan bahwa variabel pengaruh signifikan antara variabel bebas $\left(\mathrm{X}_{1}, \mathrm{X}_{2}\right)$ yaitu Islamic Service Quality dan Brand Image terhadap kepuasan nasabah sebagai variabel terikat (Y).

\section{PENUTUP}

\section{Kesimpulan}

1. Penerapan Islamic Service Quality pada PT Bank BRIS KC Citarum dilakukan secara maksimal meliputi, Konsep KeTuhanan, Pandangan Islam Terhadap Harta, Konsep Benar, Amanat, Jujur dan Adil, Compliance (kepatuhan) serta Tangibles (Bukti Fisik), Emphaty (Empati), Reliability (Kehandalan), Responsiveness (Daya Tanggap) dan Assurance (Keyakinan). Kemudian skor jawaban kuisioner yang berada pada interval baik, hal ini menunjukkan bahwa Islamic Service Quality di BRI Syariah KC Citarum Kota Bandung telah berjalan dengan baik.

2. Brand image pada BRI Syariah dalam perspektif nasabah di PT Bank BRIS KC Citarum sudah baik dengan hasil penelitian yang menujukkan bahwa skor jawaban kuisioner yang berada pada interval Baik. Dengan demikian, dapat disimpulkan bahwa persepsi para nasabah terkait brand image yang dimiliki oleh BRI Syariah KCI Citarum Kota Bandung sudah baik. Oleh karena itu, maka dapat dikatakan bahwa BRI Syariah secara 
lembaga telah menjalankan principles of islamic finance yang dibangun atas larangan riba, larangan gharar, tuntunan bisnis halal, resiko bisnis ditanggung bersama dan transakasi ekonomi berlandaskan pada pertimbangan memenuhi rasa keadilan.

3. Tingkat kepuasan nasabah di BRI Syariah KC Citarum merupakan gambaran persepsi kepuasan nasabah terhadap kinerja pelayanan yang dilakukan para karyawan BRI Syariah. Hasil penelitian menunjukkan bahwa skor jawaban kuisioner yang berada pada interval Puas. Dengan demikian, dapat disimpulkan bahwa tingkat kepuasan nasabah di BRI Syariah KC Citarum Kota Bandung berada pada tingkatan kepuasan yang cukup baik.

4. Islamic Service Quality memiliki pengaruh terhadap kepuasan nasabah di BRI Syariah secara signifikan. Hal ini menunjukkan bahwa penerapan sistem pelayanan Islamic Service Quality kepada pada nasabahnya dapat menjadi faktor penentu atau menjadi tolak ukur dalam melihat sebarapa tinggi tingkat kepuasan nasabah di BRI Syariah. Sedangkan untuk Brand Image, variabel ini memiliki pengaruh terhadap kepuasan nasabah di BRI Syariah yang cukup signifikan juga.

\section{Saran}

Berdasarkan kesimpulan di atas, maka penulis mengemukakan saran-saran yang diharapkan dapat dijadikan sebagai masukan bagi BRI Syariah KC Citarum, sebagai berikut:

1. Penulis memberikan saran kepada pihak manajemen BRI Syariah KC Citarum untuk meningkatkan kualitas pelayanannya khususnya dari kecepatan karyawan dalam melayani nasabah, karyawan lebih memenuhi segala kebutuhan operasional nasabah, dari gedung yang dimiliki agar lebih terawat lagi, dan area parkir yang tersedia lebih diperluas. Hal ini dapat dilakukan melalui pelaksanaan program pelatihan pelayanan khususnya bagi para karyawan di bagian Front Office dengan materi pelayanan Service Excellent, selain itu juga pelatihan yang meningkatkan penguasaan terhadap produk perbankan yang dimiliki oleh Bank BRI Syariah.
2. Penulis memberikan saran kepada pihak manajemen BRI Syariah KC Citarum untuk senantiasa mengelola atau menjalankan strategi kualitas pelayanan para Front Officer dengan dinamis, tidak baku dan disesuaikan kondisi yang terjadi namun tetap dilandasi dengan nilai-nilai keislaman, tanpa unsurnya riba. Sehingga meskipun kondisi di lapangan bersifat dinamis, namun pencapaian visi BRI Syariah sebagai bank syariah terpercaya dapat tercapai dengan baik.

3. Untuk lebih meningkatkan Brand Image di BRI Syariah KCI Citarum, perlu menambah iklan-iklan di sosial media dan televisi atau menambah spanduk dan baligho di berbagai jalan yang dilalui orang ramai serta ditambahnya jaringan kantor dan atm agar masyarakat lebih mudah mengingat adanya BRI syariah di daerah tertentu.

4. Untuk meningkatkan kepuasan nasabahnya, maka BRI Syariah KCI Citarum Kota Bandung perlu mengupayakan meningkatkan brand image mereka sebagai bank islam dengan cara memberikan pelayanan yang berkualitas kepada nasabah. dan merancang sistem pelayanan serta fasilitas penunjang sebaik mungkin serta produk yang bener-benar syar'i untuk menjaga kepercayaan serta loyalitas nasabah yang religius

\section{DAFTAR PUSTAKA}

Al Qur'an dan Terjemahannya. 2005.

SyamilAl Qur'an. Bandung: PT. Syaamil Cipta Media.

Antonio, Muhammad Syafi'i. 2000. "Bank Syariah: Dari Teori Ke Praktik”. Jakarta: Gema Insani Press

Bank Indonesia. 2002

Cetak biru "Pengembangan perbankan syariah di Indonesia" diakses tanggal 1 September 2017 dari https://www.bi.go.id/id/ruang media /siaran.../cetakbirups.pdf

Bawono Anton. 2006.

"Multivariate Analysis dengan SPSS". Salatiga: STAIN Salatiga

Press.

Bapenas. 2016

Masterplan Arsitektur Keuangan Syariah Indonesia, diakses tanggal 
10 Agustus 2017 dari https://www. bappenasgo.id/files/ulikasi_utam Masterplan\%20Ar itektur\%20Keuangan\%20Syariah 20Indonesia.pdf

BRI Syariah. 2017

Diakses tanggal 20 September 2017 https://www.brisyariah.co.id/tenta g_kami.php?f=sejarah

Siregar Mulya. 2016

Dewan pengawas Otoritas Jasa

Keuangan, diakses tanggal 15 Agustus 2017 dari https://www. antaranews com/berit /546856/ojk-pangsa pasar perbankan-syariah 487.

Fandy Tjiptono. 2004

“Strategi Pemasaran”, edisi kedua, Yogyakarta : Andi

Husein Umar. 2007

"Metode Penelitian Untuk Skripsi

Dan Tesis Bisnis”, Jakarta: PT.

Raja Grafindo Persada

Kotler dkk, 2000

Manajemen Pemasaran, Perspektif Asia. Yogyakarta : Andi

Othman, A \& L. Owen, 2001

"AdoptingAnd Measure Customer Service Quality (SQ) in Islamic Banks: A Case Study in Kuwait Finance House", International Journal of Islamic Financial Services Vol.3 No.1 diakses pada tanggal 28 Juli 2017 dari https://pdfs.semanticscholar.org/15fc/a dfff972d487c2dd1dfe853bc0e9960853 2e.pdf

World Muslim Population, 2017

http://www.pewforum.org/2011/0/ 27/table-muslim-populationbycountry/. diakses Tanggal 7 Agustus 2017.

Zeithaml, L. Valerie A., Parasuraman, A.,Berry, Leonardo L., 1988, "Servqual; A Multiple Item Scale for Measuring Consumer Perception of Service Quality", Journal and Retailing, Vol. 64, Spring, pg. 12-40. Diakses pada tanggal 13 Agustus 2017 dari http://ejournal.upi.edu/index.php/ db/article/view/13094/7740 